\title{
Study on the suitability of wheat varieties for the production of malt syrup and its quality assessment
}

Faraz Ahmed ${ }^{1,2 *}$, Saghir Ahmed Sheikh ${ }^{1}$, Shahzor Gul Khaskheli ${ }^{1}$, Aasia Akbar Panhwar ${ }^{1}$, Riaz Hussain Mari ${ }^{1}$, Aneela Yousaf ${ }^{1}$, Saira Memon ${ }^{1}$, Naeem Akhtar Arain ${ }^{1}$ and Majid Ali Kalhoro ${ }^{1}$

1. Institute of Food Sciences \& Technology, Sindh Agriculture University, Tandojam, Pakistan

2. College of Food Sciences and Technology, Shanghai Ocean University, China

*Corresponding author's email:Farazahmed909@yahoo.com

\section{Citation}

Faraz Ahmed, Saghir Ahmed Sheikh, Shahzor Gul Khaskheli, Aasia Akbar Panhwar, Riaz Hussain Mari, Aneel Yousaf, Saira Memon, Naeem Akhtar Arain and Majid Ali Kalhoro. Study on the suitability of wheat varieties for the production of malt syrup and its quality assessment. Pure and Applied Biology. Vol. 11, Issue 2, pp608-615. http://dx.doi.org/10.19045/bspab.2022.110062

\begin{tabular}{llll}
\hline \hline Received: 09/06/2021 & Revised: 26/08/2021 & Accepted: 03/09/2021 & Online First: 18/09/2021 \\
\hline \hline
\end{tabular}

\section{Abstract}

Currently, people are opting not that much tasty but sustaining foods have become evident. It surrounds a preserved by product utilization of germinated grains and malt extracts. This article represents studies at the influence of the wheat malt syrup percentage and germinated grain at the significance of done product. The study was carried out to examine the suitability of wheat varieties (i.e. benazir, Anmol and SKD-1(Sakrand-1) for the production and quality evaluation of malt syrup. Product quality was evaluated according to organoleptic and physicochemical indicators and nutritional value of malt syrups. The result releveled significantly different $(\mathrm{P}<$ $0.05)$ average values. In case of raw wheat varieties significantly higher $(\mathrm{P}<0.05)$ average moisture, ash, fat, protein, crude fiber and carbohydrates content were found in Benazir followed by Anmol and SKD-1(Sakrand-1). For malt syrup, significantly higher $(\mathrm{P}<0.05)$ average $\mathrm{pH}$ value, moisture, turbidity, titratable, total soluble solids and protein content was found in malt syrup of benazir followed by Anmol and SKD-1(Sakrand-1). The result also revealed that average for sensory attributes i.e. color, taste, aroma and overall acceptability were also remained significantly higher $(\mathrm{P}<0.05)$ in malt syrup prepared from Benazir followed by Anmol and SKD-1(Sakrand-1) wheat varieties. It is concluded from present study that all wheat varieties are suitable for production of malt syrup.

Keywords: Extract, Malt syrup, Nutritional value, Proximate, Processing and Wheat qualities

\section{Introduction}

Wheat (Triticum aestivum L.) is the leading origin of human dietetics as well as a part of our regular dietary requirements. Wheat is actually a dominant meal; it is being grown in country on eight million hectares with endowment approximately $13.7 \%$ and it is really necessary in the advantage of inserting of agricultural sectors and participates at about $3 \%$ increasing quantity of flagrant domiciliary by products of Pakistan [1]. Wheat is one of the most dominant sources of 
healthy components. So it provides to $19.6 \%$ and $18.3 \%$ of total human utilization of calories and proteins, consecutively [2]. This contributes other crucial macro-and micronutrients, like as magnesium, iron folate and zinc, for the considerable part of the worldwide inhabitants. This is a vital way of such healthy components. It is as well as one of the world's top traded agricultural products with reference of quantity. The wheat traded added up to 180 million metric tons (Mt) (FAO 2019).global trade provided at least one fourth of all wheat related components of accumulation level (FAO 2019), consequently it plays a vital role in international food security. About ten thousand years ago, wheat used to be cultivated as a part of 'Neolithic revolution' wheat comprises up $30 \%$ in consequent cereal production [3] it is mostly used in bread making, wheat grain has multiple different usages. For example, many pastry material, pasta, starch, alcohol, dextrose and many others [4-5]. Wheat derivatives and wheat like flour, wheat malt and starch are mostly used in the brewing industry. The obtaining of Belgian white beers, $40 \%$ unmalted wheat and $60 \%$ barley malt is mostly used. However, the characteristics of wheat are different to one another so it mostly depends on the varieties of wheat. The set of brewers has no strict specifications for it. The main components which are used to lack resemblance the various varieties of wheat are the hardness or softness of the grain and protein content. The wheat which is mostly used brewing mostly of a soft variety contains good protein content at about $11 \%$. This variety is easily milled leading to a maximal extract yield [6]. The brewing industries are engaged to produce good quality beer and low the risk of contamination and also the costs of investments. The raw materials are the chief source to reduce the costs that impart malt and adjuncts from abroad [7]. Extract of Malt is an all-natural, nutritious and whole grain sweetener. The fundamental aim of malting is to enhance the production of enzymes of hydrolytic which are not existent in the ingeminated grains [8]. Malt syrup is obtained with the help of refined grain by guarded drying germination. The germination was shared to achieve the essential enzymes of hydrolytic, the work of these enzymes to mutant the grains for malt. The enzyme such as Endo-proteases is good for the alteration of grain. The depot protein was very much mainly gluten and hordein. In the attachment of theses, they enhance endoproteases process and activate the important proteins such as $\beta$-amylase. Sufficient changes permit the enough extraction of important components during mashing. The two essential parameters of the grain, stored in the endosperm are protein and starch [9]. The syrup of malt is natural product and it has good attributes of the present-day health conscious consumer. Malts of food are required to utilize it is on the grounds that they are reachable in various styles (for example fluid, strong, syrup) and furthermore their shading with different enzymatic, healthful, and microbiological content. It is most common technique of modern biotechnology and it is a substitute of common sugar in many industries [10]. For achieving the appropriate wheat varieties for malting and purposes, researchers are working upon wheat. China and Belgium are having common wheat variations $[11,12]$. The malt syrup can be a vital resource of important amino acids. This is the reason that malt beverages extract is not an appropriate resource of protein and it gives little amount needful nutrients. The malt syrup is enriched with B-vitamin beverages content having thiamine, riboflavin, niacin and folate. It enhances the flavor, used in syrup color or sweetness in prepared foods like cereals and baked beverages [13]. Wheat malt is used to utilize malt for brewing and food industries. 
Wheat malt is still considered as a vital product. Despite the fact that it can be longer used as a malting material [14].

\section{Materials and Methods}

The Study was achieved out on the appropriateness of wheat variations for the utilization of malt syrup including its quality rating. This experiment was managed in the food and marine resources research centre of Pakistan council of scientific and industrial research (PCSIR) complex Karachi. Wheat variations samples were orderly gotten from the research institute of Sindh Agriculture University Tandojam. Then complete samples of wheat varieties were taken to laboratory of food and marine resources research centre, PCSIR labs complex Karachi. The dust and dirt was removed out by washing and distilling. After samples were examined for the study on the appropriateness of wheat varieties to get

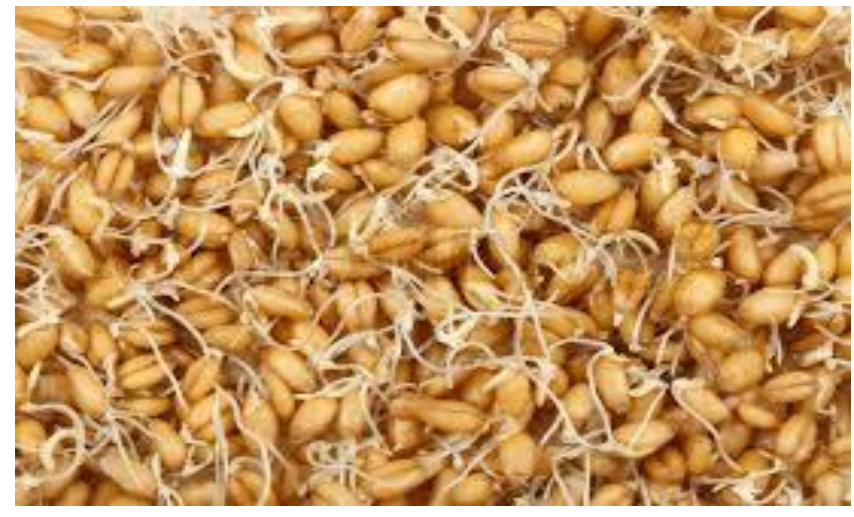

Figure 1. Germination Process of wheat grains

\section{Drying}

After sprouting content of moisture was lowered down to $(5 \%)$, these grains were dried in cabinet dries at about $65 \mathrm{C}$ for $16 \mathrm{~h}$. when they got dried all specimens were manually de-rooted were grounded into required mesh size flour. And hence were stored in sealed polythene bags to do studies on that next (Fig. 2). productions of syrup with also its quality rating.

\section{Steeping}

Rinsed and sorted wheat samples were moved into a precipitous tank having low temperature (10-20 C water. During this sheer process moisture content was raised from $12 \%$ to approximately $45 \%$. Right after 6 to 8 hours water of that tank was changed, continuously providing oxygenized and diffused oxygen so it may give respiration of wheat kernels until the preparation happens.

\section{Germination}

Rinsed and wet packs were used as a germination bed and spread over on steel trays. The sheered wheat was routinely dredged with water and was moved regularly to make sure. On $3^{\text {rd }}$ day germination and development was stopped. The process was moved out for about (44-52h); samples were germinated for 5-7 days on $16 \mathrm{C}$. and sheered out moisture of sample 43 to $46 \mathrm{C}$ (Fig. 1).

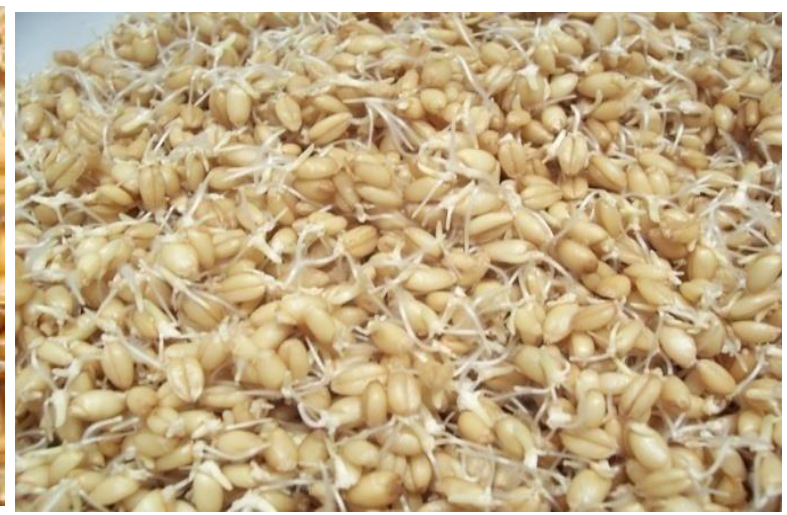

\section{Grinding}

To get the coarse powder dried kernels were cracked in a milling machine and malt was passed through. Producing thick sweet liquid called wort that cracked malt was sheered with small scale mashing water bath which is called tun, $250 \mathrm{ml}$ distilled water and about $50 \mathrm{~g}$ of milling malt was added. And mixed at 100 rpm constantly (Fig. 3). 

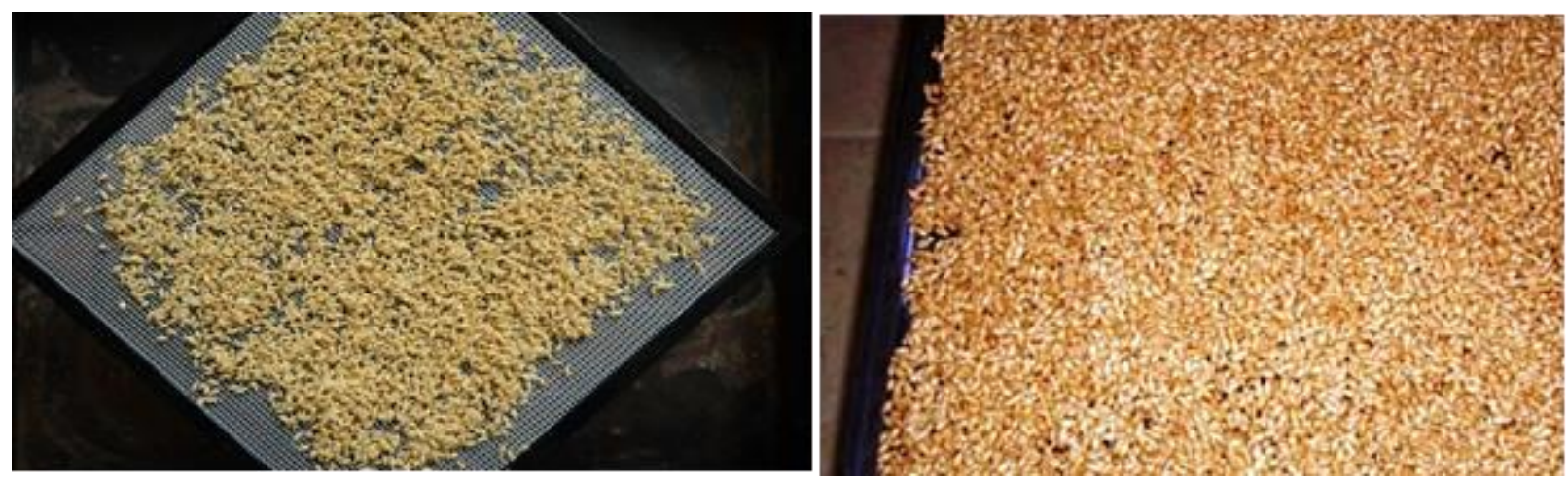

Figure 2. Drying Process of wheat grains

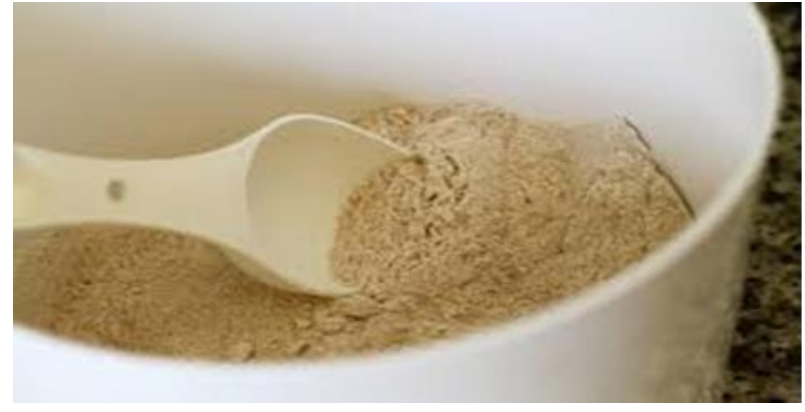

Figure 3. Grinding Process of wheat grains

\section{Preparing and Heating of Malt Extract}

Roughly 66 to $71 \mathrm{C}$ heat up the mixture on this temperature for about two hours. Throughout this time, grains having enzymes were converting starch to sugar.

\section{Proximate Analysis}

The Proximate analysis of wheat varieties comprising, ash, fat, protein, moisture, titratable acidity and subtotal soluble solids were examined by AOAC [15]. And with by difference way final carbohydrate was determined.

\section{Total Soluble Solid ( ${ }^{\circ}$ Brix)}

Total Soluble Solid of wheat malt syrup samples were examined by the help of digital Refractometer according to method described in [16].

\section{Determination of $\mathbf{p H}$}

According to method, explained by AOAC [17]. Wheat malt syrup $\mathrm{pH}$ was noted down. Standardization $\mathrm{pH}$ meter used buffer 4, 7 and 9 solutions at about 25C. Electrode (probe) was required by $\mathrm{pH}$ noticed
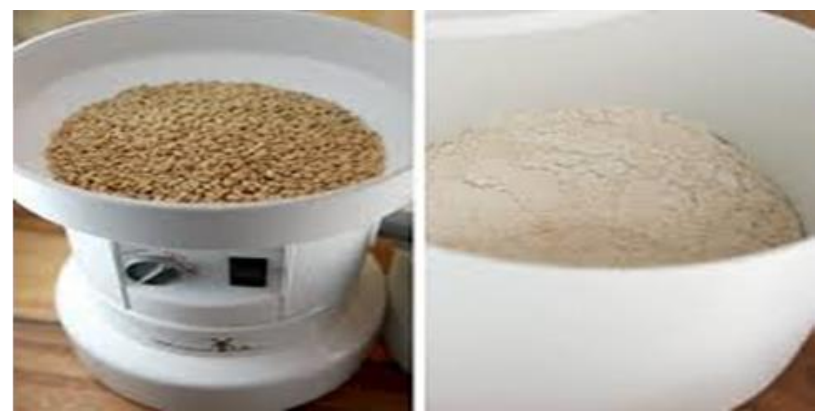

measurement sinking into every $25 \mathrm{ml}$ pipette wort sample, authorized to stable until reading gets off.

Determination of turbidity

Digital Turbidity meter is used in this experiment to determine the turbidity of liquid malt, detailed by method explained in [18].

\section{Statistical analysis}

On the basis of statistical process of synthesis of variance (ANOVA) the gained data was examined. And of the base important differences were mostly figured using minimum important comparisons (LSD) test at about $0.05 \%$. Extent of possibility with source of computerized analytical collection [19].

\section{Results and Discussion}

\section{Proximate composition of wheat varieties}

The Study was performed out on the appropriateness of wheat varieties for the manufacturing of malt syrup alongside its quality ratings. The experiment was 
performed in the Food and Marine Resources Research Centre of Pakistan Council of Scientific and Industrial Research (PCSIR) Complex Karachi. Wheat varieties samples (Benazir, Anmol and SKD-1 (Sakrand-1) were obtained from the Research Institute of Sindh Agriculture University Tandojam. The nearest structure of these chosen wheat samples are shown in table1. The malt syrups made from three varieties of wheat and moisture quantity (Benazir, Anmol and SKD1 (Sakrand-1). Benazir malt syrup contained high moisture than others. Benazir malt syrup $(9.83 \%)$ whilst anmol was too remarkably more $9.23 \%$ [20]. The ember of these wheat varieties was crucially high in benazir malt syrup (1.60\%), anmol was too notably high $1.53 \%$ [21]. Wheat varieties fat was notably high in both benazir malt syrup (1.33\%), and anmol $1.25 \%$ [22]. The wheat varieties protein was remarkably high in both benazir malt syrup (12.06\%), and anmol $11.98 \%$ [23]. The wheat varieties crude fibre was high in both benazir malt syrup (2.73\%), and anmol $2.16 \%$ [24]. The wheat varieties whole carbohydrates were crucially high in benazir malt syrup (72.45\%), whilst anmol was also significantly high $73.85 \%$ [25 (Fig. 4)].

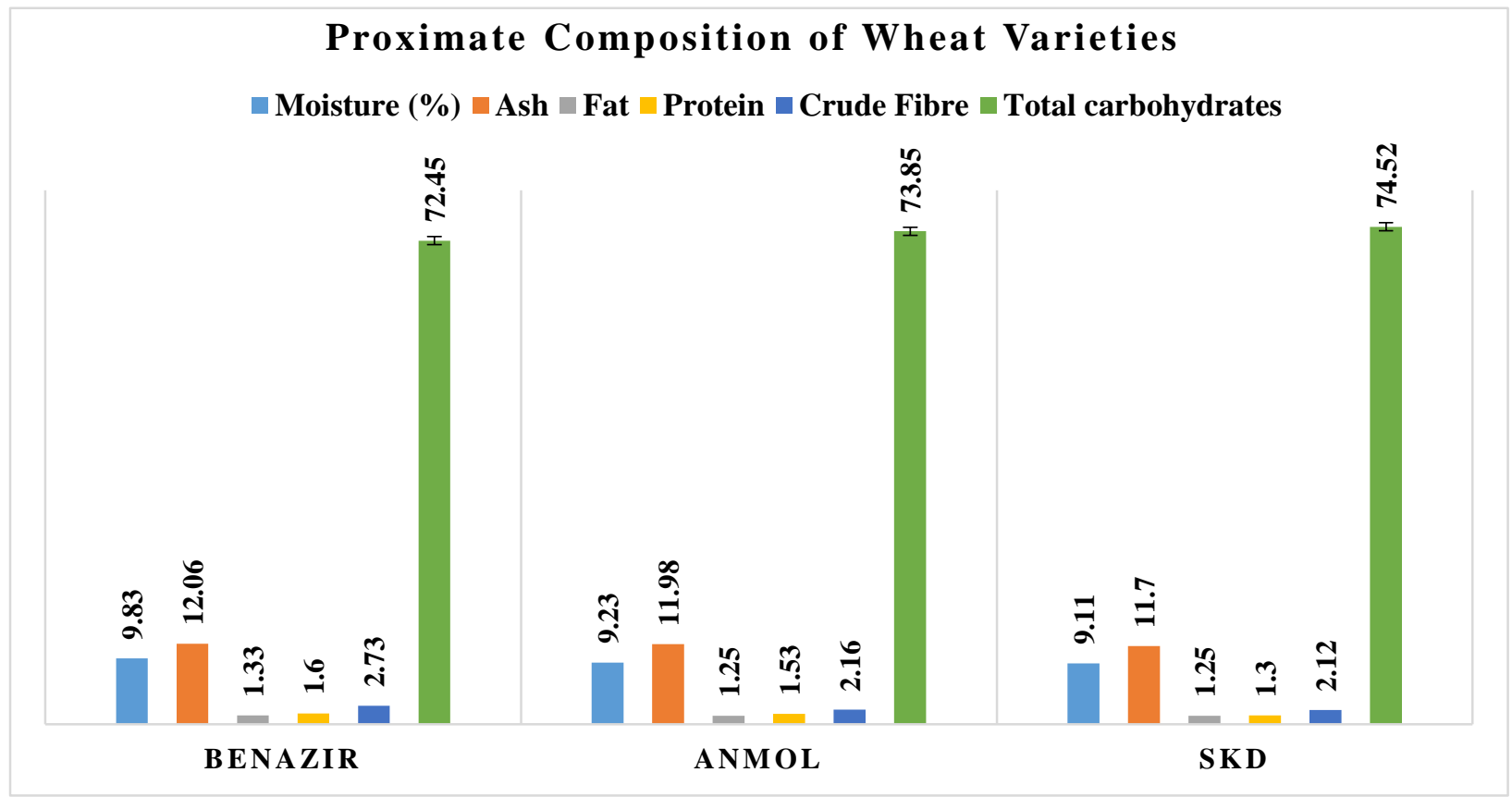

However, the differences among all varieties were statistically significant at $(\mathrm{P}>0.05)$

Figure 4. Proximate Composition of Wheat Varieties

\section{Analysis of physicochemical parameters of} wheat malt syrup

Physical and chemical variables of prepared malt syrup samples were studied in the laboratory of Food and Marine Resources Research Centre of Pakistan Council of Scientific and Industrial Research (PCSIR) Complex Karachi. The malt syrups moisture content made from three of the wheat varieties (Benazir, Anmol and SKD-1
(Sakrand-1). The wheat varieties malt syrup was notably high in both benazir malt syrup (24.90\%), and anmol (23.96\%) [26]. The malt syrups pH results (Benazir, Anmol and SKD-1 (Sakrand-1) wheat varieties was crucially high in both (6.43) in benazir, and anmol (6.07) [27]. The roiled result (Benazir, Anmol and SKD-1 (Sakrand-1) of malt syrup was remarkably high (2.27) in anmol such conclusions were pact with the detections of 
[28]. The final report of titratable acidity malt syrup made from three of the wheat varieties (Benazir, Anmol and SKD-1 (Sakrand-1) presented important variances $(\mathrm{P}>0.05)$ in one and all variations. Titratable acidity was notably high (0.80) SKD-1 (Sakrand-1) wheat malt syrup [29]. The result of TSS $\left(\right.$ Brix $\left.^{\circ}\right)$ total soluble solids (Benazir, Anmol and SKD-1 (Sakrand-1) was crucially more
(68.59) in benazir wheat malt syrup [30]. The malt syrup protein result made from three of the wheat varieties (Benazir, Anmol and SKD-1 (Sakrand-1) presented notable comparisons $(\mathrm{P}>0.05)$ in every variety. Benazir having high protein (5.35) notably wheat malts syrup these conclusions were pact with the detections of [31] (Fig. 5).

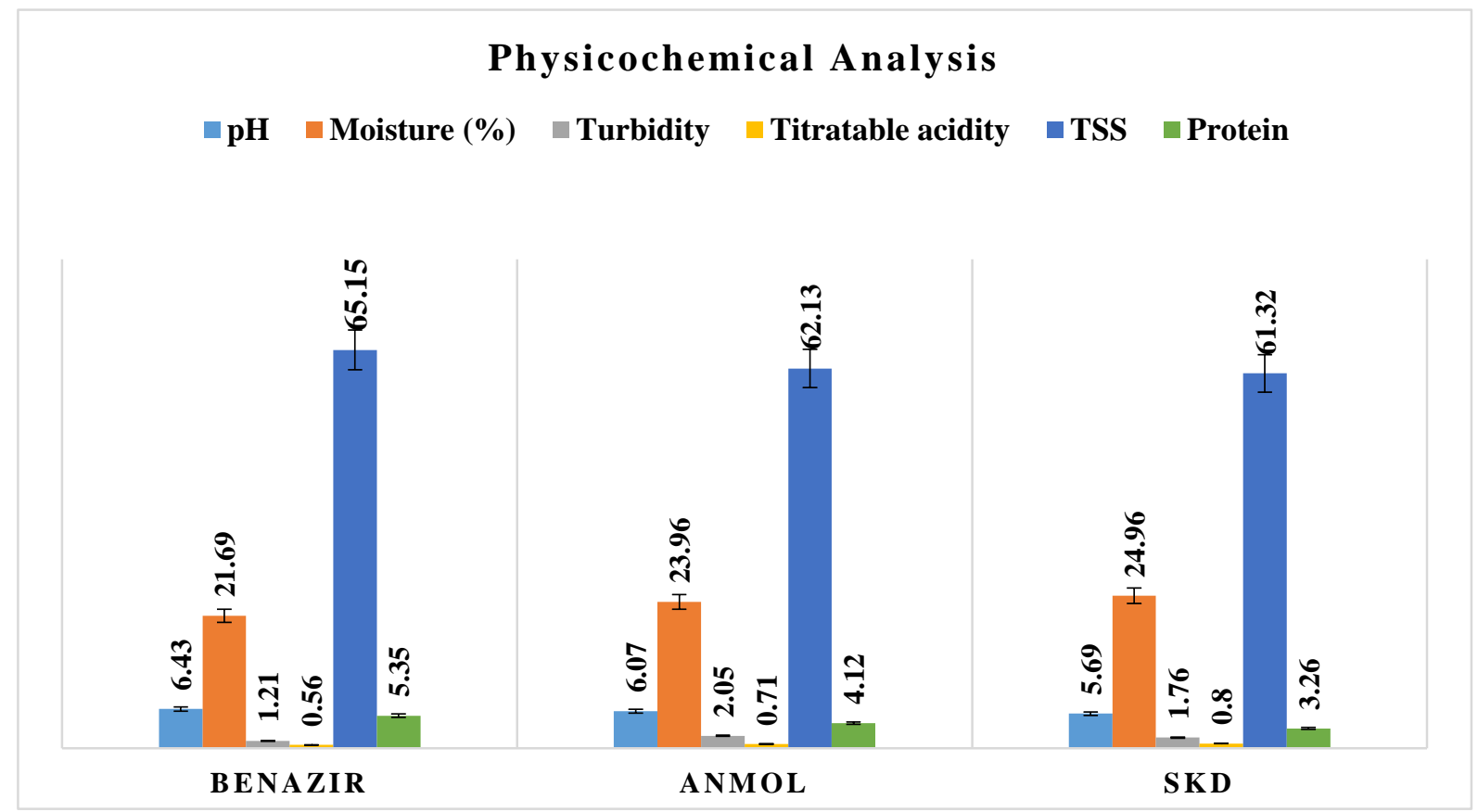

However, the differences among all varieties were statistically significant at $(\mathrm{P}>0.05)$

Figure 5. Physicochemical Analysis of wheat malt syrup

\section{Sensory evaluation}

Conclusions about stunning accredit malt syrup made from three unlike wheat variations are shown in Figure No.5. Stunning study was performed by the staff members of Food and Marine Resources Research Center, PCSIR Laboratory Complex Karachi. The result also declared that standard for stunning accredits i.e. taste, color, aroma and full convenience were too left remarkably greater $(\mathrm{P}<0.05)$ in malt syrup made from Benazir accompanied by Anmol and SKD-1 (Sakrand-1) varieties of wheat. Panel of judges got score cards (relied on nine points hedonic scale) with wheat malt syrup three varieties (Benazir, Anmol, SKD1 (Sakrand-1) to ingress the stunning attributes like as aroma, taste, color and complete adequacy of the products ways explained by [31] (Fig. 6). 


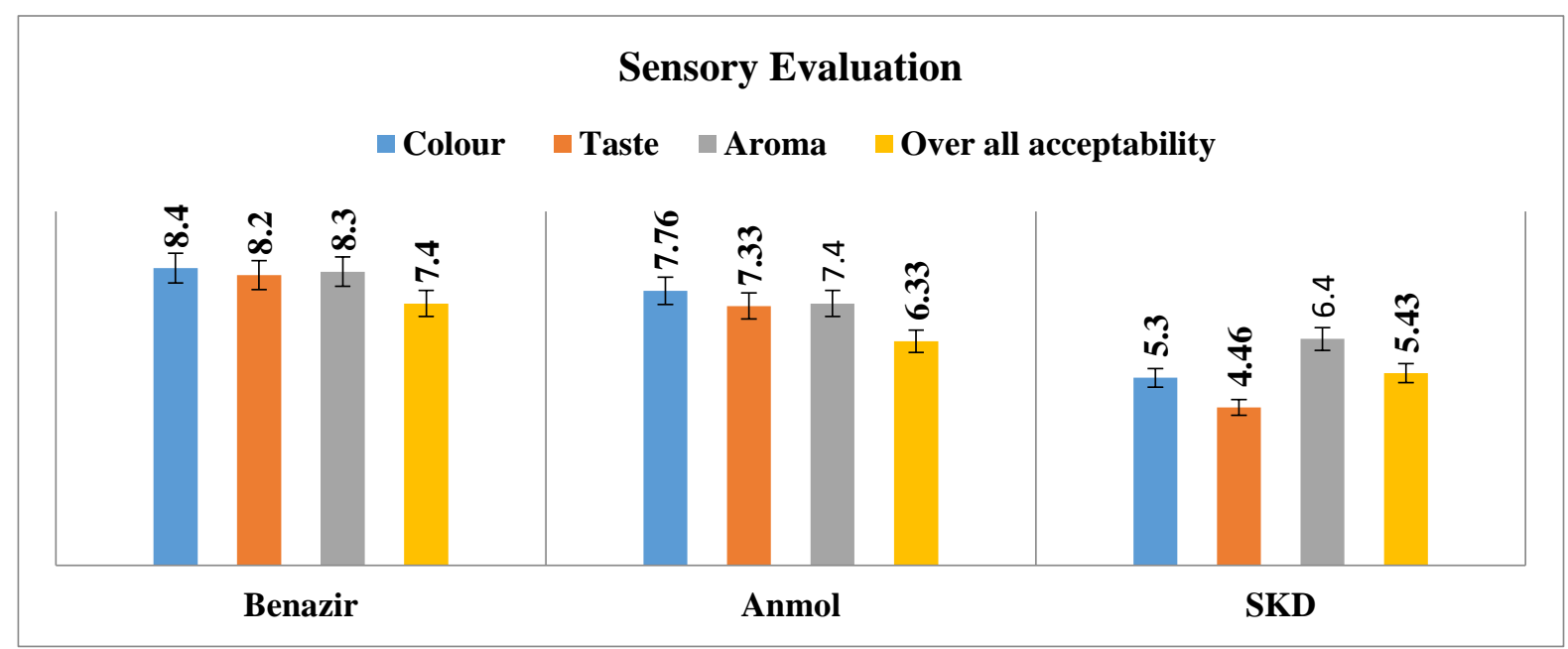

However, the differences among all varieties were statistically significant at $(\mathrm{P}>0.05)$

Figure 6. Sensory Evaluation of wheat malt syrup

\section{Conclusion and Recommendations}

It is concluded that wheat is a good source of malt syrup production. It has capability for malt syrup processing (i.e., germination, steeping and drying). In the present study it was observed in all among three varieties of wheat the suitable variety for the production of wheat malt syrup was "Benazir". The wheat cultivars feature, during the growth season the varied environmental conditions also differences in stoutness of grains affects the frameworks of chemical and malting standard of the wheat grains. Further study should be conducted in parallel manner in order to knowing their maximum shelf life of malt syrup. Further study should be conducted on quantity of the alpha amylase Enzyme which is present in the wheat varieties; consequently, upcoming research is required, getting in particular long-term studies. It is important to carry on comprehensive survey noting on effects of cultivar linked factors, also proper soil modification, on the standard of wheat planned for malting.

\section{Authors' contributions}

Conceived and designed the experiments: F Ahmed, SA Sheikh, SG Khaskheli \& AA Panhwar, Performed the experiments: F Ahmed, Analyzed the data: RH Mari \& A Yousaf, Contributed materials/ analysis/ tools: S Memon,
NA Arain \& MA Kalhoro, Wrote the paper: F Ahmed.

\section{Acknowledgement}

This research paper is part of M.Sc. (Hons.) thesis submitted to Sindh Agriculture University, Tandojam Pakistan.

\section{References}

1. Iqbal, MA, Rahim J, Naeem W, Hassan S, Khattab Y \& Ayman ES (2021). A. Rainfed winter wheat (Triticum aestivum L.) cultivars respond differently to integrated fertilization in Pakistan. Fresenius Environ Bull 30: 3115-3121.

2. United Nations Food and Agriculture Organization (FAO), FAOSTAT (2019). Food and Agriculture Data. Available online: http://faostat3.fao.org (accessed on 1 June 2018).

3. Velimirović A, Jovović Z \& Pržulj N (2021). From neolithic to late modern period: Brief history of wheat. Genetika 53(1): 407-417.

4. ACQUAAH G (2007). Principles of Plant Genetics and Breeding-Chapter 1: History and role of plant breeding in society. Student reference. Faculty of Agricultural Sciences. National University of Córdoba.

5. Jovović, ZD, Mandić N, Pržulj A, Velimirović Ž \& Dolijanović (2017). Genetic resources of wheat (triticum sp.) In montenegro. $22^{\text {nd }}$ international symposium on biotechnology, čačak 10- 11. 03. 2017. Book of Proc 1: 99-107. 
6. Sompong R, Siebenhandl-Ehn S, Linsberger MG \& Berghofer E (2011). Physicochemical and antioxidative properties of red and black rice varieties from Thailand, China and Srilanka. Food Chem (124): 132-140.

7. Saithalavi KM, Bhasin A \& Yaqoob M (2021). Impact of sprouting on physicochemical and nutritional properties of sorghum: a review. J of Food Meas and Charac 1-15.

8. Rani H \& Bhardwaj RD (2021). Quality attributes for barley malt: The backbone of beer. $J$ of Food Sci.

9. Salomón-Torres R, Valdez-Salas B \& Norzagaray-Plasencia S (2021). Date Palm: Source of Foods, Sweets and Beverages. In The Date Palm Genome. Springer Cham 2: 3-26.

10. Jin $\mathrm{YH}, \mathrm{Du} \mathrm{JH}$, Zhang KL \& Zhang XC (2011). Effects of wheat starch contents on malt qualities. $J$ of the Inst of Brew 117(4): 534-540.

11. Depraetere SA, Delvaux F \& Delvaux FR (2004). "Wheat variety and barley malt properties: influence on haze intensity and foam stability of wheat beer. $J$ of the Inst of Brew 110(3): 200-206.

12. Alka V, Manisha M \& Pinky B (2014). Barley Foods and Health: Opportunities Ahead.International Conference on Intelligent Agriculture. 63

13. Z. Jin B, Zhou J \& Gillespie et al. (2018). Production of deoxynivalenol (DON) and DON-3-glucoside during the malting of Fusarium infected hard red spring wheat. Food Control 85: 6-10.

14. AOAC (2012). Official Methods of Analysis of AOAC International. $19^{\mathrm{tH}}$ edition. AOAC International, Gaithersburg, Maryland, USA.

15. AOAC (2000). Official Method of Analysis of AOAC international. $17^{\text {th }}$ ed. The Association of Official Analytical Chemists.

16. AOAC (2004). Association of official analytical chemists - official methods of analysis. 18th Edition. Arlington: AOAC International.

17. Veleirinho B (2009): Lopes-da-Silva. JA Proc Biochem (44): 353-356.

18. Student, Edition of statistix version 8.1 (Statistix 2006).
19. Konvalina P, Stehno Z, Moudry J (2009). The critical point of conventionally bred soft wheat varieties in organic farming systems. Agro Res7(2): 801-810.

20. Al-Eid SM (2006). Effect of nitrogen and manure fertilizer on grain quality, baking and rheological properties of wheat grown in sandy soil. J Sci of Food and Agri 86(2): 205211.

21. Kumar P, Yadava RK, Gollen B, Kumar S, Verma RK, Yadav S (2011). Nutritional Contents and Medicinal Properties of Wheat. Life Sci Medi Res 22: 1-10.

22. Ali, N, Ali A \& Ali Z (2002). Effect of organic and inorganic fertilizers on wheat yield. Exp Agric 38(04): 55-61.

23. Michael O, Ameh. Dick I, Gernah, Bibiana D \& Igbabul (2013). Physicochemical and Sensory Evaluation of Wheat Bread. Food and Nutr Sci 4: 43-48.

24. Sivasankar B (2002). Food Quality, in Food Processing and Preservation. Prentice-Hall of India Private Limited, New Delhi. 345.

25. Jin, Y, Du J, Zhang K, Xie L \& Li P (2012). Relationship between Kolbach index and quality parameters of wheat malt. J Inst Brew (118): 57-62.

26. Jin, YH, Du JH, Zhang K \& Zhang X (2011). Effects of wheat starch contents on qualities. J Inst Brew 117(4): 534-540.

27. Chai Y, Jin Y, Du J, Li J \& Zhang K (2015). Partial characterization of $\beta$ - d-xylosidase from wheat malts. J Inst Brew 121(3): 338342.

28. Young J Du K, Zhang L, Xie \& Li P (2012). Relationship between Kolbach index and quality parameters of wheat malt. J Inst Brew (118): 57-62.

29. Bhatty RS (1996). Production of Food Malt from Hull-less Barley. Am Assoc of Cereal Chem 73(1): 75-80.

30. Wijngaard HH, Ulmer HM, Neumann M \& Arendt EK (2006). The effect of steeping time on the final malt quality of buckwheat. $J$ Inst Brew 111(3): 275-281.

31. Larmond E (1977). Laboratory Methods for Sensory Evaluation of Foods. Research Branch, Canada Department of Agriculture Publication No.1637. 